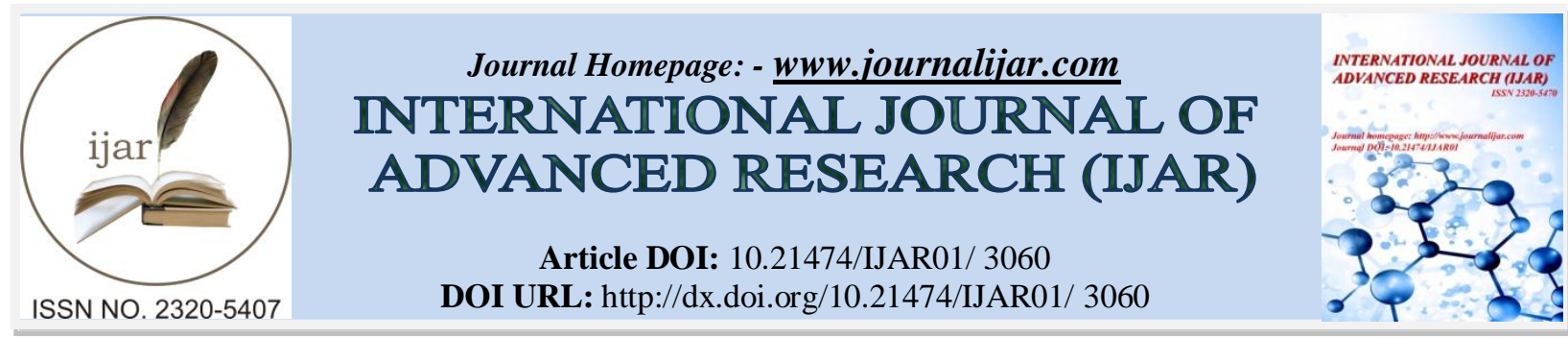

RESEARCH ARTICLE

\title{
A CRITICAL EVALUATION OF THE IMPACT OF RELIGION ON COLLECTIVIST FAMILIES' MEAL SOCIAL INTERACTION BEHAVIOUR IN SIERRA LEONE
}

Sheku Kakay and James Mulkeen.

\section{Manuscript Info}

Manuscript History

Received: 01 December 2016

Final Accepted: 29 December 2016

Published: January 2017

Key words:-

Culture, religion, family/consumer

behaviour, social interaction,

collectivism

\section{Abstract}

The symbolism of religionin the Sierra Leonean collectivist society is encouraged to promote increased interdependency and social bonding among families that share similar beliefsystem. This beliefis further accentuated and translated at the dinner table when interacting socially at mealtimes. The concept of religion is very topical in the everyday lives of Sierra Leonean consumers/families, which largely determines their food purchase and consumption behaviour. This study critically evaluates the impact religion has on families and how it affects the way they interact socially at mealtimes. As a consequence, the paper elaborates and highlights the degree of influence Islam and Christianity have on the meal social interaction behaviour of families in Sierra Leone, which is considered as one of the prime factors responsible for the increased drive forcollectivism. The authors evaluated the scope of the influence of religion on families' meal consumption behaviour and provided a comparative analysis of its influence on different gender groups.

Copy Right, IJAR, 2016,. All rights reserved.

\section{Introduction:-}

Religion is predominantly a key influencer of most Sierra Leonean families' food consumption behaviour, especially those inclined to practice the Islamic faith. Despite the symbolism attached to religion by different social groups, it has evidently over the years been influenced by families' cultural values and traditional practices. As a consequence, the mixing up of families' spiritual practices with cultural and/or traditional practices have made it increasingly difficult for Sierra Leoneans, irrespective of their religious faith and conviction, to discern or draw a dividing line between the two (cultural values/traditional practices and spiritual belief). Religion has principally been advanced by many theorists, for example, Cohen and Varnum (2016); and Kassim and Zain (2016), as one of the key influencers of collectivism, as most individuals in such societies are heavily reliant on others or their community in shaping their own identity. Rozman (2014) argued that religion is promulgated in most collectivist societies to foster interdependence and promote group-orientation, which can be used to strengthen new and existing bond between and among people. Ji et al (2016) concluded that religion is one of the most important factors of collectivism, as it can be used to pacify and build harmonious relationship between and among individuals. It is evident from these perspectives and the findings of this study that religion in the Sierra Leonean context is used mainly for building social relationship between and among individuals, as a forum for learning and sharing ideas, a platform for enhancing interdependence, a domain for social integration and an avenue for fostering unity within communities. 
This fundamentally influences their meal social interaction behaviour. Sierra Leoneans are surrounded by lots of religious practices such as making sacrifices for ancestral spirits, God's influence of everything in their daily lives and livelihoods, and prayers, which affects their food consumption behaviour as it conveys meaning that are significant to them and which are interpreted based on their understanding. This view was supported by Horta et al (2013); Judd et al (2014); and De Backer et al (2015), who stated that food tastes are shaped by family religious norms and socialisation processes, emphasising that natural tastes are founded on social constructions which have been elaborated over generations. Koenig (2013); Beagan et al (2014); and Delaney and McCarthy (2014), on the other hand, attributed food taste of working class individuals to "a taste of necessity", arising from the lack of choice and enjoyment of the sensation of feeling full. Koenig (2013) suggested that the idea of taste itself is a middle-class concept since it presupposes freedom of choice, whereas the disadvantaged classes can only have a taste for what they are anyway condemned to ... This argument is glaring in the Sierra Leonean collectivistic culture, where, as a result of religious restrictions certain groups of people refrained from consuming certain type of food products.

It is profoundly important to acknowledge that many of the factors that influence Sierra Leonean families' meal consumption behaviour are largely shaped by their religious and/or cultural beliefs, which fundamentally define their food choice. Consequently, these religious differences provides the driving force for not only families' food choices, but fundamentally influence the degree of socialisation, food ethics and boundaries observed by individuals of different age group at mealtimes. Fisher et al (2016) defined family meal as a forum for promoting positive social interaction with other members of the family as well as contributing to better nutritional well-being of the family. However, family meal consumption in this study was defined as the traditional evening meals shared or consumed together by households as family units, but excludes foods taken away from home by household members or those consumed in restaurants or on the streets. This is because most Sierra Leonean families are less inclined to eat together outdoors with their family as a socialisation practice.

This paper discusses the influence of religion on Sierra Leonean families' meal social interaction behaviour as an arbiter of the increased collectivism experienced by most households and provides the opportunity to mirror the same argument across other parts of Africa. As a consequence, the paper further critically analysed the influence of religious factors such as: spiritual beliefs, cultural values, traditional practices and social bonding have on families' meal social interaction behaviour. This was significant as it helps outline clearly the religious factors stakeholders perceived as influencing families' meal consumption behaviour in the Sierra Leonean context. Perry-Jenkins (2013); and Perez (2014) argued that there is little or no empirical evidence, models or frameworks to explain the influence of religionon family meal social interaction behaviour in the African context. Therefore, this research attempts to bring empirical data that provides evidence on the conceptualisation of religion and its corresponding effect on family social interaction patterns at mealtimes in Sierra Leone. It is against the backdrop of the issues raised that the researcherscritically evaluated the influence of religion on family meal consumption behaviour in the Sierra Leonean society. The researchers analysed the information and data obtained from the fieldwork to develop appropriate conclusions.

\section{Theoretical Underpinning:- Definitions of Culture:-}

The answers to these questions vary dramatically from individual to individual as there is no universally accepted definition of culture and it is unlikely that we will be able to progress towards one soon (Hanson, 2013). Culture has been defined in so many ways over the years, but none has been sacrosanct. Usunier and Lee (2009); Du Gay et al (2013) argued that culture is the transmission, creation and patterns of values, beliefs, ideas and symbols that shape human behaviour and the artefacts produced through those behaviours. DeMooij (2013, p. 26) defined "culture as the glue that binds groups together, emphasising that without cultural patterns (organised systems of significant symbols) people would have difficulty living together". Hofstede (2001, p. 9) in an earlier study defined culture as "...the collective programming of the mind, which distinguishes the members of one human group from another". In line with this definition, De Mooij (2013) reiterated that culture is what defines a human community, its individuals and social organisations, which is a set of controlled mechanisms (plans, recipes, rules, instructions, i.e. what computer engineers' call "programmes") for the governing of behaviour. Presenting a similar argument, Helliwell et al., (2014) defined culture as the shared learned behaviour, which is transmitted from one generation to another for purposes of individual and societal growth, adjustment, and adaptation. He suggested that culture is represented externally as artefacts, roles and institutions, and it is represented internally as values, beliefs, attitudes, epistemology, consciousness, and biological functioning. Individuals therefore can be clustered into cultural 
groupings based on a number of shared constructs and experiences including schemas (for example, a collectivistic orientation), beliefs (for example, attitudes toward mental health), socialisation practices (for example, controlling parenting), immigration, and language among others (De Mooij, 2013). From these definitions, it is clear that the various theorists (Hofstede, 2001; De Mooij, 2013; and Helliwell et al, 2014) views culture in a similar way, as not only the characteristic of individuals, but rather as one that encompasses a number of people who have been conditioned by the same education and life experience. Hence, they believed that people are conditioned by their socio-cultural environment to act in a certain manner (De Mooij, 2013), and that culture cannot be separated from the individual. They emphasised that culture is learned and reflects what is in the mind of the individual. Consequently, they distinguished two types of cultures - those that are visible such as symbols, rituals and heroes, on the one hand, and classified values as the invisible aspect of culture, and therefore view culture as specific to a particular group, which falls in line with the 'emic' perspective.

Supporting this view, Goodenough (1971) defined culture as a set of beliefs or standards, shared by a group of people, which help the individual decide what is, what can be, how to feel, what to do and how to go about doing it. In addition, Côté and Levine (2014) posited that culture is composed of psychological structures which individuals or groups of individuals use to guide their behaviour; and reiterated that culture consists of whatever it is that one has to know or believe in order to operate in a manner acceptable to its members. In a similar manner, Gerson (2013); and Herman (2014) defined culture as controlled human behaviours, suggesting that the totality of human activities, and of their accumulated products is subsumed under culture; noting that artefacts, intangibles such as language, norms and values, rituals, literature, music, science, as well as social and political institutions may be largely culture-oriented. From the perspectives of Goodenough (1971); Gerson (2013); Côté and Levine (2014); and Herman (2014), it is evident they believe that there is no reason for culture to be equated with the whole of one particular society. Goodenough (1971) posited that people switch into the culture that is operational within a given group, which assumes that the individual can choose the culture in which to interact at any given moment or in any given situation, subject to the overriding condition that the culture has been correctly internalised from past experiences, and therefore view culture from the 'etic' (universal) perspective.

\section{The effect of religion on culture:-}

Religion is a difficult concept to define (Ferré, 2013; Firth, 2013; and Wulff, 2014), which has resulted in many definitions (McLeod, 2013; and Timothy, 2013). Nevertheless, many researchers described religion as the external or outward expression of the inward spiritual system (Dobratz, 2013; Ivtzan, 2013; and Pompper, 2014). Johnson (2014) provided a contrary perspective to the argument by suggesting that religion is concerned with addressing the crises of human existence. He argues that religion is integral to humanity, as it addresses essential dimensions of life and its circumstances, offering resolutions that will always be in excess of any other rationalistic orientation. Kapferer et al (2009) defined religion as the construct worlds for life that are to be lived in and conditioned by ontological-cosmological ground.

In collectivistic cultures (for example, Hindu India and several East Asian countries), certain religious cultures view social connectivity as an integral part of religious life, and group affiliations are seen as important as they define religious identity (Wald and Calhoun-Brown, 2014). In addition, they noted that in collectivistic religious cultures, people are seen as fundamentally connected with each other and their communities, and pointed out that under such circumstances, people's religious and spiritual behaviour are tightly regulated through ritual and spirituality. Jiang et al (2016) defined rituals as the verbal language that confers identity, with emphasis placed on how communities are created. Arsel and Thompson (2011) reiterated that the identity of individuals depend in large measure on their feeling of belonging, highlighting that the social experiences of everyday life in the distinctive values of a particular group and in the process, a group acquires a distinctive identity, separate from others. The emphasis placed on rituals, set religion as an obligatory instrument among groups of collectivist religious cultures. This argument was also reinforced by Dörnyei and Ushioda (2013) that collectivism is often seen as relying on obligation and on overcoming one's internal desires for the good of the collective. Paine (2013) referenced the Jewish religion as one that emphasises the performance of religious duties even when the individual is not intrinsically motivated as it is often seen as praiseworthy to place the religious requirement above one's own private desire. Cleveland et al (2016) offered a political dimension to the argument by purporting that the Singaporean Government's approach towards religion is pragmatic, where religious values are seen mainly as instruments to promote national unity and maintain national identity. The view that religion is set as an obligatory instrument among certain social groups is very much opinionated as people's commitment to religion is dying very fast in most societies and a number of people from certain social groups/settings are hardly ardent followers of religion and/or religious practices, let alone promote 
ritualistic tendencies (Niebuhr, 2013). Therefore, these professed claims by the various theorists, for example, Paine (2013); and Wald and Calhoun-Brown (2014) needs a critical review to make the argument concrete and convincing as there are no empirical data to substantiate their proposition.

Reeve (2004); and Cohen and Hill (2007)developed a theoretical framework that distinguishes intrinsic and extrinsic religious values in collectivist cultures and defined 'intrinsic religion' as one that is matured, while referring to 'extrinsic religion' as immature. They further stressed that the use of extrinsic religion as one designed for instrumental purposes, including social integration. Jenkins et al (2013) noted that groups of people that share religious identity can be meaningfully viewed as sharing cultural values. This view was also purported by Han et al (2013); and Miller et al (2014) that the core element of collectivism is the assumption that groups bind and mutually obligate individuals. With so many domains of collectivism, Cohen and Hill (2007) admonished that it is vital to discern in which sense the discussion of collectivism can be viewed as they have tremendous impact on religious and spiritual identity, and motivation. Cleveland et al (2016) referenced a case of two Chinese non-Muslim youths who were convicted in court for posting inflammatory remarks against Muslims and claimed that the two men were jailed for spewing vulgarities at the Muslim Malay community. Cleveland et al emphasised that the incident led to the introduction of the Religious Harmony Declaration to remind all people of their religious obligation and reiterated that harmony is vital for peace, progress and prosperity. This indicates that religion alone cannot be used as an instrument to integrate people (Chang et al, 2013), and therefore undertaking a study that reviews the collectivist religious integration perspective is germane. Furthermore, the notion that people sharing the same religious beliefs have similar cultural values is parochial as most people in collectivist societies share similar religious beliefs, but have different cultural orientations or values (Moran, 2014).

Pirutinsky (2009) stated that the influence of religion on the functioning of humans is not monolithic and tends to fluctuate depending on the attitudes, beliefs, and behaviours promoted by the belief of the individual. A number of theorists, for example, Cohen (2009); and Moran et al (2014) suggest that religion is best understood as a source of cultural influence with a diverse and varied impact on the way family interact with each other and with society, and it is therefore important to examine the importance of religion in the meal social interaction behaviours of certain groups or families, since generalisation may prove inaccurate. On the other hand, it is evident as noted by Cohen (2009); and Moran et al (2014) that even within the broader religious categories such as Muslims, Christians and Jews, there may be within group differences in terms of belief and culture that might alter the importance of religion in the way collectivist families interact at the dinner table. Barrett (2013) noted that it is not all types of religious groups appear to be equally adaptive. For example, Protestants and Catholics place emphasis on different intrinsic and extrinsic religious values, particularly on social aspects of religious motivation (Cohen, 2009).

Cohen and Hill (2007); and Ferraro and Brody (2015) suggested that collectivistic cultures such as those of the Hindu Indians and several East Asian Countries, place greater emphasis on religious cultural values and social connectedness as an integral element of religious life, and proclaimed that under such circumstances group affiliations are seen as important in defining parts of religious identity. This argument was further reinforced by Johnson and Cohen (2013), who concluded that collectivistic religious cultures pay greater credence to connectedness among people and communities. Kitayama and Markus (2014) noted that in a collectivist religious setting individuals are more likely to see themselves as part of an encompassing social network and to act in accordance with what one perceives to be the feelings, thoughts, and actions of the others. Hofstede (2003); and Collar (2013) stressed that schisms within religious communities in collectivist societies are not encouraged, but if they do occur, they are absorbed within the context of the larger religious community. Hofstede (2003) reiterated that human beings' images of God or the gods reflect the values of human society, and professed that polytheist religions are symptomatic of collectivist societies. A number of research studies, for example, Hayton and Cacciotti (2014); Posthuma and Guerrero (2013); and Thornhill and Fincher (2014) conclude that traditional religiosity is positively associated with types of values characteristic of collectivism. It may be that because collectivism emphasises the relation to the in-group, the collectivist person would find more value in benefiting someone closer to her or him. The notion of the theorists, for example, Hofstede (2003); and Collar (2013), that schisms is not encouraged in religion can be viewed as too extreme as people of the same faith/belief may belong to different religious sects, which in itself breeds conflict and antagonism and most times a source of religious tensions (Krishnamurti, 2013).

Wald and Calboun (2014) referenced the distinction between Orthodox (i.e. the premise of acceptance of a divinely originated Torah (Hebrew bible) and adherence to the 613 biblical commandments, as interpreted in the "Talmud" 
and applied to all aspects of daily life) and non-Orthodox Judaism (which does not require strict adherence to laws and beliefs, but instead emphasises interpersonal ethics and social action and communal participation). Cohen and Hill (2007); and Kvande (2014) argued that non-orthodox Judaism represents a collectivist religion, which focuses on the expression of religiosity through social interrelation. Pirutinsky (2009); and Argyle and Beit-Hallahmi (2014) reiterated that the Orthodox Jewish doctrine and culture are explicitly centred on religious mental states such as belief in an afterlife; and a personal relationship with God founded upon faith and trust (Rosmarin et al, 2009; and Barrett, 2013). In family social interaction at meal times, most religions view the provision of the food for the family as God given, which can lead to spiritual and religious growth (Burton and Clements, 2013). Rosmarin et al (2009); and Feinson and Meir (2014) posited that despite the paucity of research on Orthodox Jews, religious mental states such as belief in God's benevolence and the utilisation of religious coping strategies are strongly linked with a better mental state, whilst research on non-Orthodox Jews found no relationship between religion, belief and mental health (Feinson and Meir, 2014).

A number of studies, for example, Sussman et al (2013); and Scales et al. (2014), have pointed to the mediating pathways through which intrinsic religiosity exerts these effects, indicating that the mechanisms are not fully known and vary across religious affiliations. A key possibility noted by Bhushan (2014) is that intrinsic religiosity acts as psychological resource that encourages protective mental states. Other researchers have suggested that beyond these mental processes, religious individuals have better social contacts (Argyle and Beit-Hallahmi, 2013; and Pargament and Lomax, 2013). Giddens (2013); and Figley and Kiser (2013) suggested that social support serves as a protection against the way families interact at the dinner table. Consequently, intrinsic religiosity may help to unify the family and influence their degree of closeness through increased social support (Wang et al., 2014). Hovey et al. (2014) posited that although extrinsic religiosity provides increased social contact, intrinsic religiosity provides a more effective social support. This implies that religion is used for instrumental purposes such as social integration as well as for community affiliation, social relationship, tradition and rituals (Cohen, 2009). Ai et al (2014); and Ledbetter and Beck (2014) supported this argument by stating that relationships formed in the context of a shared religious worldview are particularly accessible and protective when families are interacting socially at the dinner table. Consequently, there are chances of potential variation in the spiritual effects of religious beliefs across religious groups or sects and the paucity of research on the impact of religion on family meal interaction behaviour justifies the essence of conducting research on such a topical issue (Koenig, 2013; and Pressman et al, 2014).

\section{Individualism/Collectivism:-}

Martin and Manns (2014); and Yolles and Fink (2014) suggest that individualism-collectivism should be theorised along a cultural continuum rather than establishing a cultural divide as there is a tendency for both to exist in the same culture. In an earlier study, Chui and Kwok (2008) concluded that more life insurance policies are sold in individualistic cultures than in collectivistic ones, emphasising that in the former, should one die, one cannot rely on family members to support the dependents. Lu et al (2013); and Roberts (2015) noted that people with strong individualistic values emphasise autonomy, independence, and individual initiative; and the right to privacy, pleasure seeking, financial security, the need for specific friendships, and universalism, whereas individuals with strong collectivistic values tend to favour group solidarity, obligations, security, obedience, duty and personalised relationship; and promotes collective identity, emotional independence, sharing, need for stable and predetermined friendships, group decisions and particularism (Yassine-Hamdan and Pearson, 2014). The individualismcollectivism literature mainly focuses on the differences between the Western cultural values, the Middle Eastern cultural values or the Far Eastern cultural values (De Mooij, 2013; Naor et al, 2013; and Vaiman and Brewster, 2014), and it is assumed that African cultures are also collectivist (Greenfield and Cocking, 2014), which signifies that the African continent has been neglected over the years with no meaningful research conducted to verify the assertions of collectivism (McEwan et al, 2015). Therefore, the notion that collectivist cultures promote collective identity, stability, obligations and group decisions is questionable as there is evidence of the inability of families to hold things together when having social discourse at the dinner table; and Roopnarine and Hossain (2013) noted that a number of homes in Africa are built on nuclear orientation rather than extended families. Also, most collectivist homes in Africa, decisions are not made in collective rather the head of the family is the decision-maker (Kavanaugh et al, 2014).

Oh et al (2014); and Pandey and Joseph (2014) suggested that concern for belongingness leads to a tendency towards collectivism, which is expressed by an individual's identification with the collective goal of his or her group; and Parks et al (2013) recommended that priority should be given to the group as a whole, and referenced the 
Chinese cultural values as one that gives credence, importance and continuity to the kinship group (Berger et al, 2014). Slater and Tonkiss (2013); Zhao (2014); and Lee (2015) buttressed this argument by commenting that the primary concern of the majority of Chinese was how to protect and enhance their private kinship interests; and that individual sacrifices may be required in order to gain the benefits that accrue to the group. The concept of collectivism has also been shown to have significant impact on creativity and innovativeness as it has been shown to extinguish the creative spark necessary for innovation (Usunier and Lee, 2009; Anderson, 2014;Kumar, 2014). The concern for belongingness should not be seen as the primary arbiter for collectivism as most family members in Africa are afraid of being ostracised by their kinship network and as a result drives them to embrace collectivistic tendencies (Gaines, 2014). Therefore, such generalisation of collectivism needs to be re-examined in order to determine whether there are discrepancies in the argument purported by the various theorists.

\section{Family meal social interaction behavior:-}

Family meal social interaction behaviour is the meal shared by a family as a social event, which has important cultural meaning in the organisation of the family's social life with culturally specific rhythms, norms, rights, and responsibilities (Conklin et al, 2014). Neumark-Sztainer et al (2008); McIntosh (2013); and Lull (2013) reported the existence of a positive family social discourse atmosphere, when families make mealtimes a priority, and the family structure during meals protect children from disordered eating behaviours. Windram-Geddes (2013) pointed out that lack of genuine concern and disengagement during the meal times has also been associated with overweight conditions in children, as families who interact socially with their children in a direct and clear manner during mealtimes are less likely to have children with internalising symptoms. The notion that family meal social interaction behaviour reduces disorderliness and internalised symptoms is subjective as many families in certain social groups hardly sit together to have a meal, but at the same time have children whose social behaviours are orderly and responsible (Chapman, 2013; Cohen, 2013; and Firth, 2013). As a result, conducting a study to address these shortcomings is essential and significant.

Family mealtime social interaction behaviours are characterised by responsiveness to children's questions, role assignment, and that when behaviour is well regulated, the child adaptations such as enriched language development and academic achievement can be enhanced (John et al, 2013; and Seifer et al, 2014). The parenting style, generally accounts for differences in eating and family meal social intercourse behaviours, particularly when considering outcomes associated with younger children who spend more time overall eating at home with one or more parents (Fraser et al, 2014). Philips et al (2014) noted family meal social interaction behaviour is characterised by overcontrolling and restrictive attitudes and behaviours towards food, which can be associated with overweight status in children. A number of research findings, for example, Berge et al (2013); and Drotar (2014), showed that more frequent family meal social interactions are associated with better outcomes among children and adolescents. The notion by the theorists that over-controlling and restrictiveness to children's attitude and behaviour at meal times leads to obesity is questionable as many researchers have pointed to the type of food consumed by the family as the main contributors to obesity (Betoko et al, 2013; Pearce and Langley-Evans, 2013; and Pimpin et al, 2013).

\section{Methodology:-}

This research adopted the constructionist approach as its epistemological perspective, which is reliably linked with the 'lived experiences of families as it is considered an appropriate way for determining how humans make sense of their surroundings. As a consequence, this research used semi-structured face to face interviews, observation, field notes, and archival analysis as the data collection methods. The interviewees were drawn from 20 different Sierra Leonean families (husbands and wives) with differing ethic and cultural backgrounds, with a sample size of 40 . The research was conducted in the four provincial headquarter towns of Bo, Freetown, Kenema and Makeni. The data was collected using snowballing, experiential and convenience sampling techniques. The researcher used qualitative research in explaining the behaviours of families at mealtimes using inductive approach. A pilot study was conducted on four families of differing backgrounds to determine the appropriateness of the semi-structured interview protocols. The initial data collected from the four families were analysed to identify their appropriateness for the study. The initial data obtained during the pilot study were coded and analysed to determine whether the research questions and objectives have been met. This was eventually followed by the primary data collection.All the families were recruited on a voluntary basis by emphasising to them the freedom to withdraw from the research process at any time.Critical attention was given to the religious and marital backgrounds of the interviewees to ensure a fair representation of the sample obtained from the differing social groups. This was done in order to ensure equal proportional representation of the two religious groups (Christians and Muslims), and ensure that the couples interviewed were married in order to achieve the objectives of the research. The data collection process lasted for 
about two months ( 8 weeks).NVIVO 10 was used in transcribing the data obtained from the field as it gave the researcher the ability to forward and rewind the audio recorder.The data was analysed thematically by identifying the frequency at which certain issues or themes appeared in the primary data.

\section{Results and findings:-}

This section of the research discusses how religion as a doctrine affects the families' meal social interaction behaviour by outlining the various antecedents that families view as critical when having social discourse at mealtimes. Spiritual beliefs, cultural values, traditional practices and social bonding were identified as the subthemes from the data as the main issues affecting religion of the Sierra Leonean families at mealtimes. A detailed discussion of each of the sub-theme is held in the subsequent sections.

\section{Spiritual beliefs:-}

Spiritual belief in this study involves: the religious beliefs; food ethics; respect and affection; gender distinction; hierarchical credence; socialisation and education espoused by families in their meal behaviours.

\begin{tabular}{|c|c|}
\hline \multirow[t]{5}{*}{ Q.1 } & $\begin{array}{l}\text { In what ways does this spiritual belief influence the way your family interact at the } \\
\text { dinner table? }\end{array}$ \\
\hline & $\begin{array}{l}\text { Muslim Females: } \\
\text { Themes in common were: prayer; respect; provider; food ethics; food type; gratification; } \\
\text { religious beliefs } \\
\text { Differences were reflected in the following areas: protection; family unity; gender distinction; } \\
\text { obedience; God's presence; fasting; kneeling down; posture; dress code; boundaries }\end{array}$ \\
\hline & $\begin{array}{l}\text { Christian Females: } \\
\text { Themes in common were: prayer; provider; respect; gratification; food ethics; religious beliefs; } \\
\text { family unity } \\
\text { Differences were reflected in the areas of humility; success; responsibility; direction; God's } \\
\text { presence; religious faith; fearing God; way of life; food wastage; relationship building; } \\
\text { harmony; love; sharing }\end{array}$ \\
\hline & $\begin{array}{l}\text { Muslim Males: } \\
\text { Themes in common were: prayers; provider; respect; gratification; food type; religious beliefs } \\
\text { Differences were reflected in the following areas: truthfulness; cultural beliefs/values; } \\
\text { humility; food ethics; religious beliefs; God's presence; love }\end{array}$ \\
\hline & $\begin{array}{l}\text { Christian Males: } \\
\text { Themes in common were: prayer; provider; gratification; religious beliefs; blessing } \\
\text { Differences were reflected in the following domain: respect; humility; saviour; responsibility; } \\
\text { family cohesion/unity; God's presence; moral beliefs; fasting; fearing God; love; bonding }\end{array}$ \\
\hline $\begin{array}{l}\text { Observational } \\
\text { data }\end{array}$ & $\begin{array}{l}\text { A number of the interviewees observed silence at mealtimes. It was also observed that some of } \\
\text { the interviewees said 'bismillahi' or the Lord's prayer in silence before eating. The members } \\
\text { of some family used spoons when eating. The children thanked both the mother and father and } \\
\text { any elder present after eating }\end{array}$ \\
\hline $\begin{array}{l}\text { Comparative } \\
\text { summary of the } \\
\text { findings }\end{array}$ & $\begin{array}{l}\text { In comparing the food religious behaviours of Muslim and Christian females, the results show } \\
\text { that commonalities existed in the areas of prayers, God is the provider, respect, food ethics, } \\
\text { gratifying God and family religious beliefs as reflected in the views of the } 7^{\text {th }} 17^{\text {th }}, 19^{\text {th }}, 21^{\text {st }} \text {, } \text {, } 25^{\text {th }}, 31^{\text {st }}, 35^{\text {th }}, 37^{\text {th }} \text {, and } 39^{\text {th }} \text { interviewees for Muslim females and } 1^{\text {st }}, 3^{\text {rd }}, 5^{\text {th }}, 9^{\text {th }}, 11^{\text {th }}, 13^{\text {th }} \text {, } \\
15^{\text {th }}, 23^{\text {rd }}, 27^{\text {th }} \text { and } 29^{\text {th }} \text { interviewees for Christian females. For example: } \\
\text { "Well, I teach my children to pray before their meal, I also teach them to pray after their meal } \\
\text { and ask God to provide for us and also ask him to provide for the breadwinner. We also ask } \\
\text { God to promote my business, and I believe that God is making that provision as it is evident in } \\
\text { everything we are currently doing... when we are at the dinner table we expect everybody to be } \\
\text { silent and behave appropriately- no talking is allowed during dinner. After praying we sit } \\
\text { down quietly and eat..." } \\
\text { Interviewee 9, Female, Christian } \\
\text { Despite the overwhelming similarities shared by Muslim and Christian females, there were } \\
\text { marked differences in terms of the type of food consumed by each sect as the Christian females }\end{array}$ \\
\hline
\end{tabular}




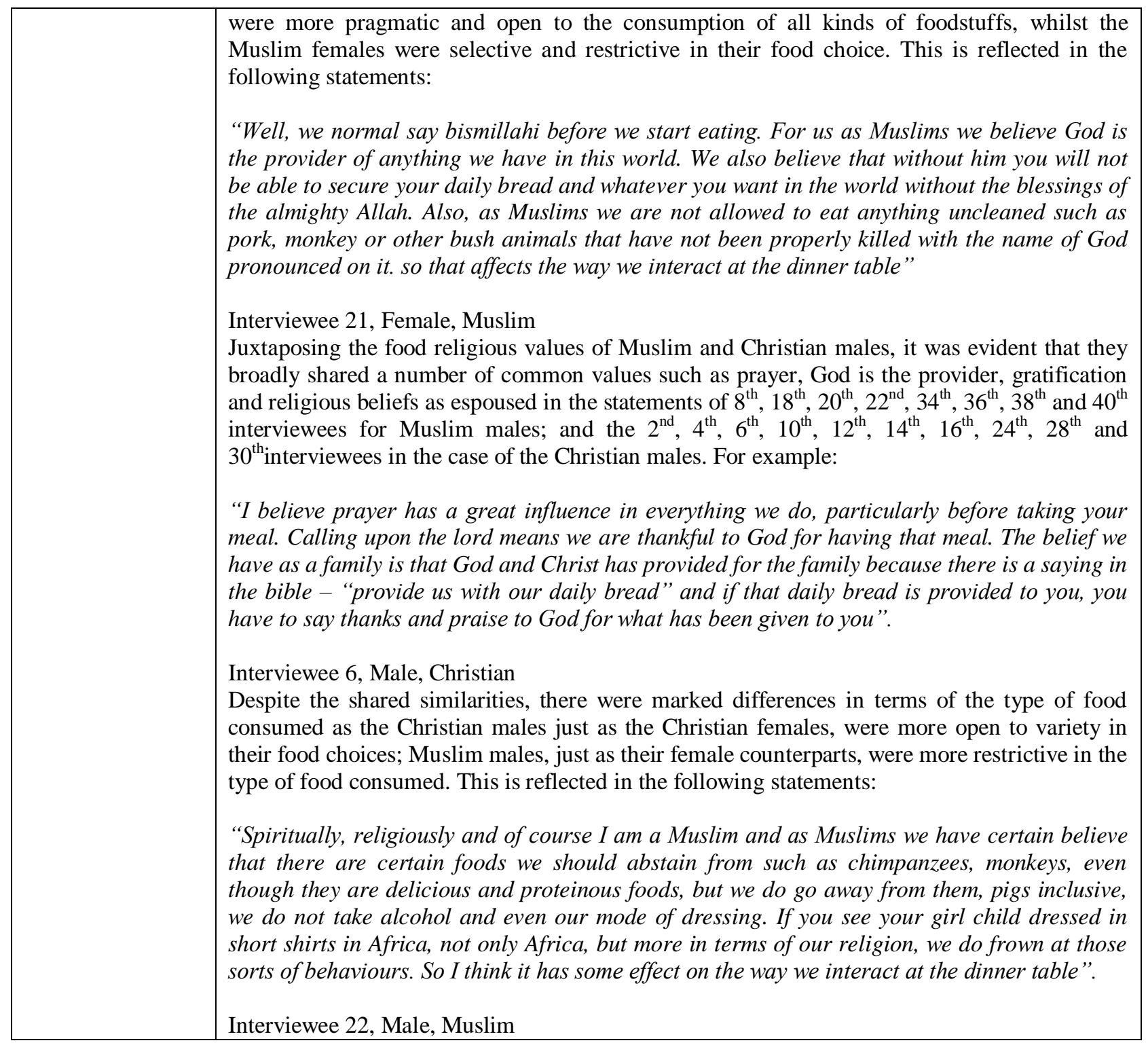

\section{Cultural values:-}

Cultural values in this study are the generally accepted standard of behaviour expected from each member of a family at mealtimes, including: food ethics; reverence for each other; hierarchy; gender differentiation; affection; and religious beliefs.

\begin{tabular}{|l|l|}
\hline Q.2 & $\begin{array}{l}\text { What cultural values influence your family's meal social interaction behaviour at the dinner } \\
\text { table? }\end{array}$ \\
\cline { 2 - 3 } & $\begin{array}{l}\text { Muslim Females: } \\
\text { Themes in common were: respect; gratification; prayer; food ethics; gender distinction }\end{array}$ \\
& $\begin{array}{l}\text { Differences were reflected in the following domains: food type; unity; politeness; sense of } \\
\text { responsibility; hierarchy; anti-social behaviour; kneeling down; Meal sharing; comportment; lion } \\
\text { share; authority }\end{array}$ \\
\cline { 2 - 2 } & $\begin{array}{l}\text { Christian Females: } \\
\text { Themes in common were: respect; prayer; food ethics; task distinction; gratification } \\
\text { Differences were reflected in the following domains: hierarchy; politeness; obedience; sympathy; } \\
\text { meal sharing; peace; greetings; love; lion share; self-identity; spiritual growth; blessing food }\end{array}$ \\
\hline $\begin{array}{l}\text { Muslim Males: } \\
\text { Themes in common were: respect; prayers; authority/control; food ethics; meal sharing }\end{array}$ \\
\hline
\end{tabular}




\begin{tabular}{|c|c|}
\hline & $\begin{array}{l}\text { Differences were reflected in the following areas: sympathy; unity; family image; sense of } \\
\text { responsibility; values; love; gratification }\end{array}$ \\
\hline & $\begin{array}{l}\text { Christian Males: } \\
\text { Themes in common were: food ethics; respect; family unity; meal sharing; prayers } \\
\text { Differences were reflected in the following domain: boundaries; sense of responsibility; } \\
\text { obedience; values; hierarchy; gratification; love; comportment; understanding; cordiality; } \\
\text { friendliness; spiritual growth; blessing food; revered God }\end{array}$ \\
\hline $\begin{array}{l}\text { Observational } \\
\text { data }\end{array}$ & $\begin{array}{l}\text { Silence was observed at mealtimes by a majority of families. Prayer was also observed by a } \\
\text { majority of families. The children of most families thanked their parents after the meal. However, } \\
\text { it was observed that a few families do not attach credence to thanking them, as their children did } \\
\text { not do so after meal. }\end{array}$ \\
\hline $\begin{array}{l}\text { Comparative } \\
\text { summary of } \\
\text { the findings }\end{array}$ & 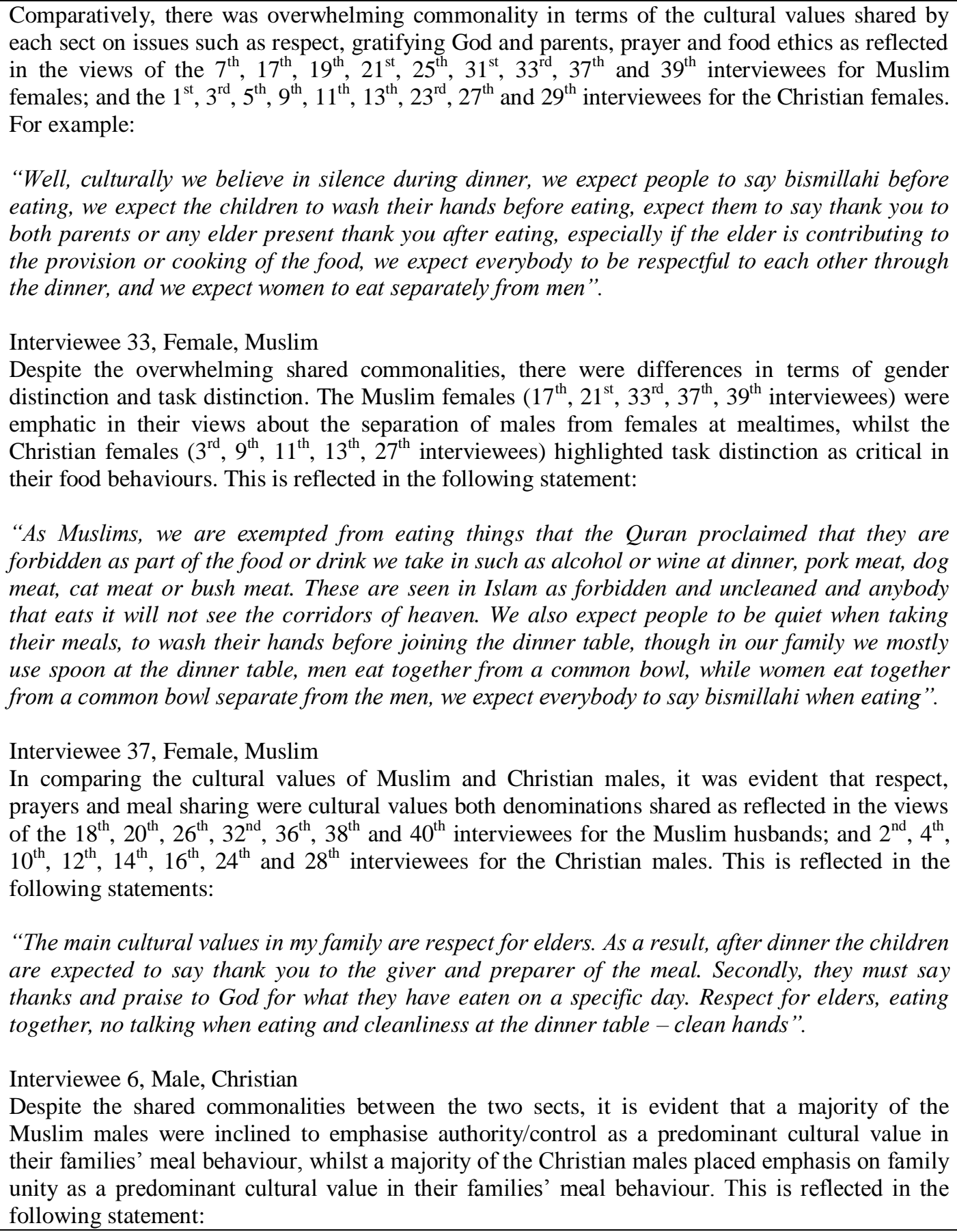 \\
\hline
\end{tabular}




\begin{tabular}{|l|l|}
\hline $\begin{array}{l}\text { "Well, as Muslims the way we eat together is that they dish in a very big bowl where all of us will } \\
\text { put our hands together as men and during the process the oldest one among you will control } \\
\text { whatever meat or whatever condiments is on top of that food. So you don't have to reach for that } \\
\text { particular meat until it is being divided among you all equally. But you have to respect the rules } \\
\text { and regulations of the elders while eating". } \\
\text { Interviewee 18, Male, Muslim }\end{array}$ \\
\hline
\end{tabular}

\section{Traditional practices:-}

Traditional practices in this study refer to the customary practices of families that are influenced by their culture or sub-culture and/or their social group or cultural settings/environment, including: food ethics; affection; modernity; respect; family religious values; hierarchy; and gender distinction.

\begin{tabular}{|c|c|}
\hline \multirow[t]{5}{*}{ Q.3 } & $\begin{array}{l}\text { What traditional practices influence your family's meal social interaction pattern at the } \\
\text { dinner table? }\end{array}$ \\
\hline & $\begin{array}{l}\text { Muslim Females: } \\
\text { Themes in common were: food ethics; gratification; prayer; sense of responsibility; sympathy } \\
\text { Differences were reflected in the following domain: family unity; respect; obedience; politeness; } \\
\text { gender distinction; peace; kneeling down; Islamic values }\end{array}$ \\
\hline & $\begin{array}{l}\text { Christian Females: } \\
\text { Themes in common were: prayers } \\
\text { Differences were reflected in the following domains: respect; food ethics; hierarchy; humility; } \\
\text { responsibility; kneeling down }\end{array}$ \\
\hline & $\begin{array}{l}\text { Muslim Males: } \\
\text { Themes in common were: prayers; food ethics; respect; gratification } \\
\text { Differences were reflected in the following areas: control; family unity; provider; truthfulness; } \\
\text { togetherness; responsibility; cooperation; fearing God; Islamic values; God provider }\end{array}$ \\
\hline & $\begin{array}{l}\text { Christian Males: } \\
\text { Themes in common were: food ethics; respect; control; prayers } \\
\text { Differences were reflected in the following domain: sense of responsibility; modernity; sympathy; } \\
\text { sharing; family unity; togetherness; appreciation; witchcraft }\end{array}$ \\
\hline $\begin{array}{l}\text { Observational } \\
\text { data }\end{array}$ & $\begin{array}{l}\text { In a majority of families, it was observed that females ate separately from males. Members of the } \\
\text { family washed their hands from a common bowl. The families said prayers before eating and } \\
\text { silence was observed throughout the dinner. The females were observed bringing food to the } \\
\text { dinner table for the males. The children thanked the parents after dinner. Females cleaned and } \\
\text { cleared the table of dishes after eating. }\end{array}$ \\
\hline $\begin{array}{l}\text { Comparative } \\
\text { summary of } \\
\text { the findings }\end{array}$ & $\begin{array}{l}\text { Comparing the traditional practices of Muslim and Christian females, the findings show that they } \\
\text { share commonality only in prayers as most Christian females }\left(1^{\text {st }}, 3^{\text {td }}, 5^{\text {th }}, 9^{\text {th }}, 13^{\text {th }}, 27^{\text {th }} \text { and } 29^{\text {th }}\right. \\
\text { interviewees) indicated that traditional practices do not influence their families' meal behaviour, } \\
\text { whilst Muslim females }\left(7^{\text {th }}, 17^{\text {th }}, 19^{\text {th }}, 21^{\text {st }}, 25^{\text {th }}, 31^{\text {st }}, 33^{\text {th }}, 35^{\text {th }} \text { and } 39^{\text {th }} \text { interviewees) commonly }\right. \\
\text { shared food ethics, gratifying parents, prayers, sense of responsibility and sympathy as being } \\
\text { central in their traditional practices. For example: } \\
\text { "Just as I said, the younger ones fetch water to the dinner table before meal, the children say } \\
\text { thank you after meal, prayers before eating, quietness is expected from everybody when eating, } \\
\text { sympathy and politeness at the dinner table". } \\
\text { Interviewee } 1 \text {, Female, Christian } \\
\text { A majority of the Muslim and Christian males share commonalities in the area of prayers, respect } \\
\text { and food ethics as reflected in the views of the } 18^{\text {th }}, 22^{\text {nd }}, 26^{\text {th }}, 32^{\text {nd }}, 34^{\text {th }}, 36^{\text {th }}, 38^{\text {th }} \text { and } 40^{\text {th }} \\
\text { interviewees for Muslim males and the } 2^{\text {nd }}, 4^{\text {th }}, 6^{\text {th }}, 10,12^{\text {th }}, 14^{\text {th }}, 24^{\text {th }} \text { and } 28^{\text {th }} \text { interviewees for the } \\
\text { Christian males. This is reflected in the following statement: } \\
\text { "Well, before eating, we expect everybody to wash their hands, we expect everybody to be silent } \\
\text { when eating, we expect everybody to respect each other and particularly elders, and we expect } \\
\text { everybody to say bismillahi before putting the food in his/her mouth". }\end{array}$ \\
\hline
\end{tabular}


Interviewee 36, Male, Muslim

However, there are marked differences between the two denominations (Christian and Muslim males) in the area of control and parental gratification as a majority of Muslim males are more inclined to expect gratification from their children after a meal, whilst the Christian males are inclined to implement control at mealtimes. For example:

"I am a Muslim, so we strictly follow Islamic norms. Before eating you have to pray and before you do anything you have to pray first. After eating you say thanks to the almighty God".

Interviewee 26, Male, Muslim

\section{Social bonding:-}

Social bonding in this study is the degree of closeness established by each family either internally within the family or externally with others in their natural settings, including: socialisation; reverence; affection; education; food ethics; and family religious values.

\begin{tabular}{|c|c|}
\hline Q.4 & $\begin{array}{l}\text { In what ways does social bonding influence your family's social interaction pattern at meal } \\
\text { times? }\end{array}$ \\
\hline & $\begin{array}{l}\text { Muslim Females: } \\
\text { Themes in common were: food ethics; moral education; control } \\
\text { Differences were reflected in the following domains: respect; advice source; family image; prayer; } \\
\text { participation; happiness; training; preaching; learning; sharing ideas; modern approaches; } \\
\text { direction; food type }\end{array}$ \\
\hline & $\begin{array}{l}\text { Christian Females: } \\
\text { Themes in common were: family unity; respect; affection; prayer } \\
\text { Differences were reflected in the following domains: meal sharing; compatibility; sympathy; sense } \\
\text { of responsibility; social bonding; love }\end{array}$ \\
\hline & $\begin{array}{l}\text { Muslim Males: } \\
\text { Themes in common were: cultural values; sharing; family unity; togetherness; prayer } \\
\text { Differences were reflected in the following areas: respect; control; family image; social group; } \\
\text { understanding; peace; success; food type }\end{array}$ \\
\hline & $\begin{array}{l}\text { Christian Males: } \\
\text { Themes in common were: family unity; sharing; togetherness; prayer } \\
\text { Differences were reflected in the following domain: obedience; values; sense of belonging; social } \\
\text { event; community gathering; oneness; cordiality; raising awareness; communication }\end{array}$ \\
\hline $\begin{array}{l}\text { Observational } \\
\text { data }\end{array}$ & $\begin{array}{l}\text { In one of the families, a pastor was observed joining the family at mealtimes. Lengthy prayer } \\
\text { before eating was observed. The male child was asked to eat separately from his dad. The pastor } \\
\text { and dad ate together and silence was observed throughout the dinner. After dinner a lengthy } \\
\text { discussion was held. The wife cleared the table after meal. }\end{array}$ \\
\hline $\begin{array}{l}\text { Comparative } \\
\text { summary of } \\
\text { the findings }\end{array}$ & 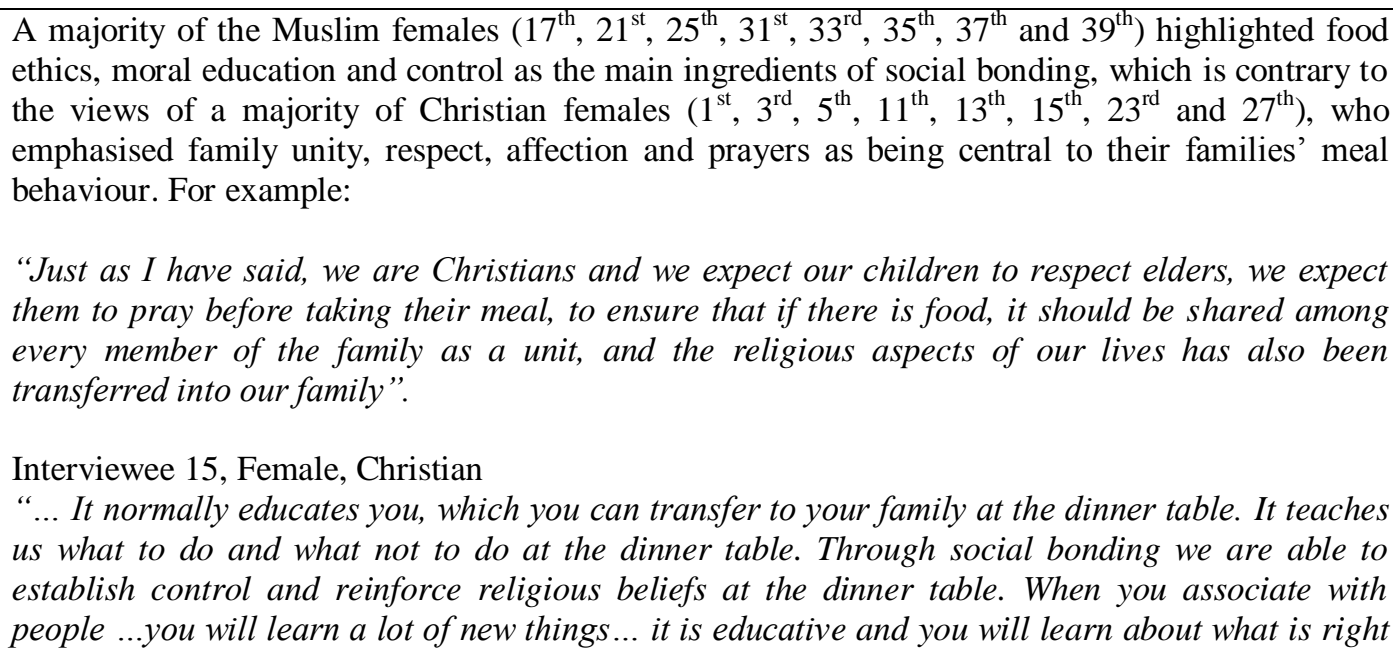 \\
\hline
\end{tabular}


and what is wrong and the right way to behave”.

Interviewee 39, Female, Muslim

Family unity, prayer, togetherness and meal sharing are commonalities emphasised by a majority of the Muslim $\left(8^{\text {th }}, 20^{\text {th }}, 22^{\text {nd }}, 36^{\text {th }}, 38^{\text {th }}\right.$ and $40^{\text {th }}$ interviewees $)$ and Christian $\left(2^{\text {nd }}, 6^{\text {th }}, 12^{\text {th }}, 16^{\text {th }}\right.$ and $24^{\text {th }}$ interviewees) males as influencers of their families' food behaviour. This is reflected in the following statement:

“...we believe in sharing, because we believe in give and take...it brings us together and gives us the opportunity to interact with other people in the community"

Interviewee 24, Male, Christian

However, there are differences in terms of cultural values as a majority of the Muslim males see social bonding as a way of sharing their values with others as reflected in the following statement:

"...social bonding plays a great role in shaping the behaviour of the children and it is also a way of teaching the children our cultural values”.

Interviewee 40, Male, Muslim

\section{Discussions:-}

Discussion of the impact of religion on families and businesses is sub-categorised into spiritual beliefs, cultural values, traditional practices and social bonding, each of which are discussed in detailed below:

\section{The impact of spiritual beliefs:-}

Under the perspective of religion, the results show that spiritual beliefs is ingrained in families across Sierra Leone as a majority of interviewees (Muslim and Christian females, and Muslim and Christian males) emphasised that their families have religious values that guide their behaviour; their families held prayers before eating as they believe that God is responsible for providing food for their families; and that God must be respected and thanked at all times (before and after meal) for the food provided for their families. Despite the similarities, a majority of Muslim and Christian females emphasised food ethics such as silence at mealtimes, washing of hands before eating, and the nonwastage of food as fundamental aspects of their families' spiritual beliefs; a factor less emphasised by a majority of the Muslim and Christian husbands. This may be due to their gender responsibility and the keen attention they pay to the proper functioning of the family as a whole. It is also evident from the results that a majority of the Muslim females and males were more selective in their families' food choices due to their religious beliefs, whereas the Christian females and males were more pragmatic and open to all kinds of foods. The results also show that even within the same religion and gender classification, for example, Muslim females, differences emerged including: God protects the family; family unity; gender distinction; obedience; God's presence; fasting; kneeling down; posture at mealtimes; dress code; and food boundaries. Other issues raised by a significant number of the interviewees as spiritually influencing their families' meal behaviour include: humility; success; responsibility; direction; observing God's presence; demonstrating the fear of God; building relationship with others; harmony; love; sharing; truthfulness; respect; and God is the saviour. This implies that a majority of the interviewees embraced family religious values; prayers; God makes provision for the family; and respecting and gratifying God as fundamental to their families' way of life. This further implies that despite the religious divide between the Muslim and Christian families, there are shared commonalities between them, and that the so called 'division/schism' between the two sects is man-made or at least blurring: may be due to acculturation. The fundamental role of prayers in families' meal behaviour emphasised in this study reflects those of Burton and Clements (2013); Dobratz (2013); and Ivtzan (2013), that prayer at family mealtimes brings unity and that difference in the type of food eaten by families are largely influenced by spiritual beliefs. The aspect of family religious values were also emphasised by Cohen and Hill (2007); Reeve (2004); and Cleveland et al (2016) as instruments to promote national unity and maintain national identity. However, this study brings a new dimension to the argument by highlighting specific issues such as gratifying God at mealtimes; food ethics; God protecting the family from social ills; God is the provider of the food eaten by the family; and gender distinction at mealtimes as fundamental factors affecting families' meal behaviour as well as businesses. This implies that spiritual beliefs largely influence the kind of food families eat and/or drink, which sometimes influences the kind of people they associate with. These 
were the gaps the study identified in the literature such as: the generalisation of the impact of spiritual beliefs on families and businesses, as lacking sufficient evidence and argument, and which it sought to fill.

The impact of cultural values:-

On the issue of cultural value as a religious domain, a majority of the interviewees (Muslim and Christian females, and Muslim and Christian males) emphasised respect for elders, food ethics and prayers before eating as fundamental to their families' meal behaviour. Despite the avowed similarities, a majority of the Muslim and Christian females emphasised the need for gratifying God and parents, and observing food ethics at mealtimes as being symbolic in their families' meal behaviour. In comparison, a majority of the Muslim and Christian males emphasised sharing meals with others as fundamental to their families' religious cultural values. Furthermore, the results showed that a majority of Christian males were emphatic about family unity as a significant cultural value; a majority of Muslim males were emphatic about the symbolism of authority/control as fundamental cultural values; a majority of the Christian females were emphatic about the significance of task distinction as symbolic cultural values; and a majority of Muslim females were more emphatic about gender distinction as fundamental cultural values. It was also evident from the results of this study that even within the same religion and gender group, there were minor differences in cultural values, including: hierarchy; politeness; obedience; sympathy; meal sharing; peace; greetings; love; husband getting the lion share; self-identity; spiritual growth; and blessing of the food. Other issues identified by a minority of all interviewees in relation to cultural values include: food type; unity; sense of responsibility; anti-social behaviour; kneeling down; comportment; authority; family image; family values; gratification; boundaries; obedience; understanding; cordiality; friendliness; and revered God, which they emphasised are important cultural values in their families at mealtimes. This suggests that a majority of the interviewees see respect for elders, food ethics and prayers as essential cultural values in their families' meal behaviour, and that the Muslim and Christian females attached higher importance to the gratification of God than those of their male counterparts (Muslim and Christian males). This argument reflects those of Ferraro, G., \& Brody (2013); Cohen and Hill (2007); and Jenkins et al. (2013), who emphasised that cultural values and social connectedness are an integral element of societal religious life. Despite the similarities shared with Ferraro, G., \& Brody (2013); Cohen and Hill (2007); and Jenkins et al. (2013) about cultural values which is largely generic, this study was able to specify respect, family religious values, prayers, gratification of God and parents, and food ethics as fundamental cultural values affecting families. This implies that cultural values are becoming an important overlap of religious values, as it is difficult to discern between religion and cultural values in most Sierra Leonean family. The generic description of cultural values by previous studies led the researcher to believe that there were gaps in their findings, which this study helped to address.

\section{The impact of traditional practices:-}

In emphasising the impact of traditional practices as a religious domain, a majority of the interviewees (Muslim and Christian females, and Muslim and Christian males) emphasised prayer as a predominant factor in their families' meal behaviour. Despite the shared similarity, a majority of the Christian females suggested that traditional practices do not influence their families' meal behaviour, which was contrary to the views of Muslim females, a majority of whom posited additional factors, including: food ethics; gratifying parents; sense of responsibility; authority/control and sympathy as major influencers of their families' meal behaviour. This is consistent with the views of a majority of the Muslim and Christian males, who reiterated respect and food ethics as fundamental in their families' meal behaviour. In addition, a majority of Muslim males emphasised gratification of God and parents as symbolic traditional practices, whilst Christian males were emphatic about authority/control as fundamental traditional practices. This suggests that a majority of interviewees were inclined to use traditional practices at mealtimes, and that traditional practices are not predominantly embraced by most Christian females due to acculturationand/or other factors such as urbanisation, though their male counterparts (Christian males) are more inclined to use them. This is consistent with the views of Guerrero (2013); and Thornhill and Fincher (2014), who identified traditional practices as influencers of the behaviour of collectivist societies and proclaimed that, they are positively associated with people's religiosity. It is evident from the findings of this study that the views of Guerrero (2013); and Thornhill and Fincher (2014) are too generic and broad to be meaningful to future researchers as they failed to identify specifically the traditional practices that influenced people's behaviour. As a consequence, this study provides detailed and specific traditional practices that influenced families' meal behaviour, including: prayers; respect and food ethics; sympathy; sense of responsibility; and gratifying parents as symbolic traditional practices shared by a majority of families in Sierra Leone. This implies that despite a majority of Muslim families (males and females) still embrace traditional practices as part of their social interaction at mealtimes, the findings of this study showed that there is a gradual deviation from these practices, and presumably, there are greater tendencies for such deviations to increase 
in the future. These were the gaps identified by the researcher as being too broad to be meaningful to future researchers, which are succinctly fulfilled by this study.

\section{The impact of social bonding:-}

In analysing the impact of social bonding as a religious factor on families' meal behaviour, a majority of Muslim females purported food ethics, moral education and authority/control as fundamental in their families' meal behaviour, which is contrary to the views of a majority of Christian females, who emphasised family unity, respect, affection and prayer as intrinsic in their families' meal behaviour. However, a majority of Muslim and Christian males emphasised family unity, prayer, togetherness and meal sharing as essential to the way their families behaved at mealtimes. This indicates that family unity and prayer are central to the family religious values of Christian females, Muslim males and Christian males, but offers distinct set of values/beliefs to the Muslim females, and the way people socialise in society may vary from one group to the other due to cultural, gender, age, regional or religious differences. As a consequence, even within the same family, sometimes bonding is limited to people of the same age group or gender. This implies that a majority of the interviewees view social bonding as a fundamental influencer of their families' meal behaviour. The results also showed that even within the same gender and religious domain of families, a minority of the interviewees demonstrated significant social differences in the way they relate with others, including: advice source; family image; participation; happiness; training; preaching; sharing ideas; direction; social group; understanding; peace; success; compatibility; sympathy; sense of responsibility; love; obedience; values; social event; community gathering; oneness; cordiality; raising awareness; and communication. The same argument was advanced by Arsel and Thompson (2011) that the identity of individuals depend in large measure on their feeling of acceptance, highlighting that the social experiences of everyday life is the distinct values of a particular group, emphasising that in the process, the group acquires a distinct identity, separate from others. This argument was further reinforced by Kitayama and Markus (2014), who noted that, individuals are more likely to see themselves as part of an encompassing social network and to act in accordance with what one perceives to be the feelings, thoughts, and actions of the others. Despite these similarities, this study is the first to specify the various components of social bonding and its impact on families in Sierra Leone, including: food ethics; moral education; control; family unity; respect; affection; prayer; togetherness; neighbours; and meal sharing as fundamental to the way Sierra Leonean families interact at mealtimes. This suggests that irrespective of the commonalities shared about social bonding by families, differing perspectives are bound to emerge either due to their lack of awareness of its symbolism, the upbringing of individuals or the type of social groups they interact with over the years. These gaps were what led the researcher to question the validity of the broad concept of social bonding used by earlier theorists such as: the generalisation of the view that individuals and businesses act in accordance with the feelings, thoughts, and actions of the others, which has been sufficiently filled by this study.

\section{Conclusion:-}

It is evident from the findings of this study that religion transcends the concept of spiritual beliefs and that in fact it is ingrained in the cultural, educational, traditional, ethical and social construct of families, which help fosters a healthy environment and raises children's awareness about the symbolism of God. This profoundly increases humility, respect and obedience among family members at mealtimes, and teaches children moral ethics, prevents families from experiencing health hazards and imbibes sense of responsibility in children. In retrospect, the study highlights religion as a fundamentally influencerof the type of food purchased and/or consumed by families asChristians were more pragmatic and open to consuming all types of food unlike their Muslim counterparts. Another fundamental influence of religion is that it promotes the increased drive for gender differentiation and role distinctionat families' mealtimes, whichis used to showcase male dominance and female subservience. Consequently, this limitsthe association between males and females at mealtimes, which is increasingly used to define responsibility at the dinner table. The implications of this conclusion are that religion can have both positive and negative influence on families' meal behaviour. This is because it can be used for building the public image of the family, shaping the character of the children for the future good of society and by bringing them closer to God. Contrarily, religion adverse affect families as it can be used to restrict social interaction and connectivity between and among family members due to gender and age differences, which significantly promote biasness at mealtimes. 


\section{Reference:-}

1. Ai, A. L., Weiss, S. I., \&Fincham, F. D. (2014). Family factors contribute to general anxiety disorder and suicidal ideation among Latina Americans. Women's Health Issues, 24(3), e345-e352.

2. Anderson, E. N. (2014). Caring for Place: Ecology, Ideology, and Emotion in Traditional Landscape Management. Left Coast Press.

3. Argyle, M., \& Beit-Hallahmi, B. (2014). The psychology of religious behaviour, belief and experience. Routledge.

4. Arsel, Z., \& Thompson, C. J. (2011). Demythologizing consumption practices: how consumers protect their field-dependent identity investments from devaluing marketplace myths. Journal of Consumer Research, 37(5), 791-806.

5. Barrett, J. L. (2013). Exploring Religion's Basement. Handbook of the Psychology of Religion and Spirituality, 234.

6. Beagan, B. L., Chapman, G. E., Johnston, J., McPhail, D., Power, E. M., \&Vallianatos, H. (2014). Acquired Tastes: Why Families Eat the Way They Do. UBC Press.

7. Berge, J. M., Wall, M., Larson, N., Loth, K. A., \&Neumark-Sztainer, D. (2013). Family functioning: Associations with weight status, eating behaviours, and physical activity in adolescents. Journal of Adolescent Health, 52(3), 351-357.

8. Berger, R., Silbiger, A., Herstein, R., \& Barnes, B. R. (2014). Analyzing business-to-business relationships in an Arab context. Journal of World Business, 50(3), 454-464.

9. Betoko, A., Charles, M. A., Hankard, R., Forhan, A., Bonet, M., Saurel-Cubizolles, M. J., ...\& de LauzonGuillain, B. (2013). Infant feeding patterns over the first year of life: influence of family characteristics. European journal of clinical nutrition, 67(6), 631-637.

10. Bhushan, B. (2014). Ageing, Religiosity and Mental Health: Some Reflections. Social Work in Mental Health: Areas of Practice, Challenges, and Way Forward, 300, 153.

11. Breinlinger, S., \& Kelly, C. (2014). The Social Psychology of Collective Action. Taylor \& Francis.

12. Chang, F. H., Coster, W. J., \& Helfrich, C. A. (2013). Community Participation Measures for People With Disabilities: A Systematic Review of Content From an International Classification of Functioning, Disability and Health, Perspective. Archives of physical medicine and rehabilitation, 94(4), 771-781.

13. Chapman, D. (2013). Home \& Social Status Ils 111. Routledge.

14. Chiu, C. Y., \& Hong, Y. Y. (2013). Social psychology of culture. Psychology Press.

15. Chui, A. C., \& Kwok, C. C. (2008). National culture and life insurance consumption. Journal of International Business Studies, 39(1), 88-101.

16. Cleveland, M., Rojas-Méndez, J. I., Laroche, M., \& Papadopoulos, N. (2016). Identity, culture, dispositions and behavior: A cross-national examination of globalization and culture change. Journal of Business Research, 69(3), 1090-1102.

17. Cohen, A. (2013). Custom and politics in urban Africa: A study of Hausa migrants in Yoruba towns. Routledge.

18. Cohen, A. B. (2009). Many forms of culture. American psychologist, 64(3), 194.

19. Cohen, A. B., \& Hill, P. C. (2007). Religion as culture: Religious individualism and collectivism among American Catholics, Jews, and Protestants. Journal of Personality, 75(4), 709-742.

20. Cohen, A. B., \&Varnum, M. E. (2016). Beyond East vs. West: social class, region, and religion as forms of culture. Current Opinion in Psychology, 8, 5-9.

21. Collar, A. (2013). Religious Networks in the Roman Empire: The Spread of New Ideas. Cambridge University Press.

22. Conklin, A. I., Forouhi, N. G., Surtees, P., Khaw, K. T., Wareham, N. J., \&Monsivais, P. (2014). Social relationships and healthful dietary behaviour: Evidence from over-50s in the EPIC cohort, UK. Social Science \& Medicine, 100, 167-175.

23. Côté, J. E., \& Levine, C. G. (2014). Identity, formation, agency, and culture: A social psychological synthesis. Psychology Press.

24. De Backer, C. J., Fisher, M. L., Poels, K., \&Ponnet, K. (2015). "Our" food versus "my" food. Investigating the relation between childhood shared food practices and adult prosocial behavior in Belgium. Appetite, 85, 60-64.

25. De Mooij, M. (2013). Global marketing and advertising: Understanding cultural paradoxes. Sage Publications.

26. Delaney, M., \& McCarthy, M. B. (2014). Saints, sinners and non-believers: the moral space of food. A qualitative exploration of beliefs and perspectives on healthy eating of Irish adults aged 50-70. Appetite, 73, 105-113. 
27. Dobratz, M. C. (2013). "All my saints are within me": Expressions of end-of-life spirituality. Palliative and Supportive Care, 11(03), 191-198.

28. Dörnyei, Z., \& Ushioda, E. (2013). Teaching and researching: Motivation. Routledge.

29. Drogendijk, R., \& Martín, O. M. (2015). Relevant dimensions and contextual weights of distance in international business decisions: Evidence from Spanish and Chinese outward FDI. International Business Review, 24(1), 133-147.

30. Drotar, D. (Ed.). (2014). Measuring health-related quality of life in children and adolescents: Implications for research and practice. Psychology Press.

31. Du Gay, P., Hall, S., Janes, L., Madsen, A. K., Mackay, H., \& Negus, K. (2013). Doing cultural studies: The story of the Sony Walkman. Sage.

32. Evans, I. M. (2015). How and Why Thoughts Change: Foundations of Cognitive Psychotherapy. Oxford University Press.

33. Feinson, M. C., \& Meir, A. (2014). Exploring mental health consequences of childhood abuse and the relevance of religiosity. Journal of interpersonal violence, 30(3), 499-521.

34. Ferraro, G., \& Brody, E. K. (2015). Cultural Dimension of Global Business. Routledge.

35. Ferré, F. (2013). Basic modern philosophy of religion. Routledge

36. Figley, C. R., \& Kiser, L. J. (2013). Helping traumatized families. Routledge.

37. Firth, R. (2013). Rank and Religion in Tikopia (Routledge Revivals): A Study in Polynesian Paganism and Conversion to Christianity. Routledge.

38. Fisher, M., Milos, D., Baum, F., \& Friel, S. (2016). Social determinants in an Australian urban region: a 'complexity' lens. Health promotion international,31(1), 163-174.

39. Fraser, J., Waters, D., Forster, E., \& Brown, N. (2014). Paediatric Nursing in Australia: Principles for practice. Cambridge University Press.

40. Gaines Jr, S. O. (2014). Culture, ethnicity, and personal relationship processes. Routledge.

41. Gerson, E. M. (2013). Some Problems of Analysing Cultural Evolution. Developing Scaffolds in Evolution, Culture, and Cognition, 44, 265.

42. Giddens, A. (2013). The transformation of intimacy: Sexuality, love and eroticism in modern societies. John Wiley \& Sons.

43. Goodenough, W.H. (1971), Culture, Language and Society. Reading MA: Modular publications, 7, AddisonWesley

44. Greenfield, P. M., \& Cocking, R. R. (Eds.). (2014). Cross-cultural roots of minority child development. Psychology Press.

45. Han, J., Ling, J., \& Lim, A. (2013). Emotional Appeal in Recruiting Advertisement: Unpacking National Cultural Differences. In Academy of Management Proceedings (Vol. 2013, No. 1, p. 10743). Academy of Management.

46. Hanson, F. A. (2013). Meaning in culture. Routledge.

47. Hayton, J., \& Cacciotti, G. (2014). 8 culture and entrepreneurship: empirical evidence for direct and indirect effects. Handbook of Research On Entrepreneurship: What We Know and What We Need to Know, 147, 111112.

48. Helliwell, J. F., Wang, S., \& Xu, J. (2014). How Durable are Social Norms? Immigrant Trust and Generosity in 132 Countries (No. w19855). National Bureau of Economic Research.

49. Herman, G. (2014). Towards a Biological Re-Interpretation of Culture. Journal of Law and Social Sciences $(J L S S), 3(2), 1$.

50. Hofstede, G. (2001). Culture's consequences: Comparing values, behaviours, institutions, and organizations across nations (2nd ed.). Thousand Oaks, CA: Sage Publications.

51. Hofstede, G. (2003) Culture's consequences: Comparing values, behaviours, institutions and organisations across nations, $2^{\text {nd }}$ Edition. London, McGraw Hill.

52. Horta, A., Truninger, M., Alexandre, S., Teixeira, J., \& da Silva, V. A. (2013). Children's food meanings and eating contexts: schools and their surroundings. Young Consumers: Insight and Ideas for Responsible Marketers, 14(4), 312-320.

53. Hovey, J. D., Hurtado, G., Morales, L. R., \& Seligman, L. D. (2014). Religion-based emotional social support mediates the relationship between intrinsic religiosity and mental health. Archives of Suicide Research, 18(4), 376-391.

54. Ivtzan, I., Chan, C. P., Gardner, H. E., \&Prashar, K. (2013). Linking religion and spirituality with psychological well-being: examining self-actualisation, meaning in life, and personal growth initiative. Journal of religion and health, 52(3), 915-929. 
55. Jenkins, R. (2014). Social identity. Routledge

56. Jenkins, R. (2014). Social identity. Routledge.

57. Ji, M., Hui, E., Fu, H., Watkins, D., Tao, L., \& Lo, S. K. (2016). Effects of a culture-adaptive forgiveness intervention for Chinese college students. British Journal of Guidance \& Counselling, 44(3), 335-346.

58. Jiang, X., Flores, H. R., Leelawong, R., \& Manz, C. C. (2016). The effect of team empowerment on team performance: A cross-cultural perspective on the mediating roles of knowledge sharing and intra-group conflict. International Journal of Conflict Management, 27(1), 62-87.

59. John, A., Halliburton, A., \& Humphrey, J. (2013). Child-mother and child-father play interaction patterns with pre-schoolers. Early Child Development and Care, 183(3-4), 483-497.

60. Johnson, K. A., Li, Y. J., \& Cohen, A. B. (2013). Fundamental social motives and the varieties of religious experience. Religion, Brain \& Behavior,5(3), 197-231.

61. Johnson, K. A., Li, Y. J., \& Cohen, A. B. (2013). Fundamental social motives and the varieties of religious experience. Religion, Brain \& Behavior,5(3), 197-231.

62. Johnson, P. L., Knauss, L. G., Faran, M., \& Ban, P. (2014). Military Children and Programs That Meet Their Needs. Care of Military Service Members, Veterans, and Their Families, American Psychiatric Association Publishing

63. Joyce, J. A., O’Neil, M. E., Stormshak, E. A., McWhirter, E. H., \&Dishion, T. J. (2013). Peer Associations and Coping The Mediating Role of Ethnic Identity for Urban, African American Adolescents. Journal of Black Psychology, 39(5), 431-454.

64. Judd, S. M., Newton, J. D., Newton, F. J., \& Ewing, M. T. (2014). When nutritional guidelines and life collide: family fruit and vegetable socialisation practices in low socioeconomic communities. Journal of Marketing Management, 30(15-16), 1625-1653.

65. Kapferer, B., Eriksen, A., \& Telle, K. (2009). Religiosities toward a Future-in Pursuit of the New Millennium. Social Analysis, 53(1), 1-16.

66. Kassim, N. M., \& Zain, M. M. (2016). Quality of lifestyle and luxury purchase inclinations from the perspectives of affluent Muslim consumers. Journal of Islamic Marketing, 7(1), 95-119.

67. Katic, P., \& Morris, J. (2016). Targeting investments in small-scale groundwater irrigation using Bayesian networks for a data-scarce river basin in Sub-Saharan Africa. Environmental Modelling \& Software, 82, 44-72.

68. Kavanaugh, K., Nantais-Smith, L. M., Savage, T., Schim, S. M., \& Natarajan, G. (2014). Extended Family Support for Parents Faced with Life-Support Decisions for Extremely Premature Infants. Neonatal Network: The Journal of Neonatal Nursing, 33(5), 255-262.

69. Kitayama, S., \& Markus, H. R. (2014). Culture and the Self: Implications for Cognition, Emotion, and Motivation. College Student Development and Academic Life: Psychological, Intellectual, Social and Moral Issues, Routledge.

70. Koenig, H. G. (2013). Is religion good for your health?: The effects of religion on physical and mental health. Routledge.

71. Koenig, H. G. (2013). Is religion good for your health?: The effects of religion on physical and mental health. Routledge.

72. Krishnamurti, J. (2013). Facing a world in crisis: What life teaches us in challenging times. Shambhala Publications.

73. Kumar, V. (2014). Understanding Cultural Differences in Innovation: A Conceptual Framework and Future Research Directions. Journal of International Marketing, 22(3), 1-29.

74. Kvande, M. N., Reidunsdatter, R. J., Løhre, A., Nielsen, M. E., \&Espnes, G. A. (2014). Religiousness and social support: A study in secular Norway.Review of Religious Research, 57(1), 87-109.

75. Ledbetter, A. M., \& Beck, S. J. (2014). A Theoretical Comparison of Relational Maintenance and Closeness as Mediators of Family Communication Patterns in Parent-Child Relationships. Journal of Family Communication, 14(3), 230-252.

76. Lee, R. (2015). Guardianship of the elderly with diminished capacity: the Chinese challenge. International Journal of Law, Policy and the Family,29(1), 1-14.

77. Lu, L. C., Chang, H. H., \& Yu, S. T. (2013). Online shoppers' perceptions of e-retailers' ethics, cultural orientation, and loyalty: an exploratory study in Taiwan. Internet Research, 23(1), 47-68.

78. Lull, J. (2013). China turned on: Television, reform and resistance. Routledge.

79. Martin, H. B. K., \& Manns, H. (2014). Communication Across Cultures. Cambridge University Press.

80. McEwan, C., Hughes, A., \& Bek, D. (2015). Theorising middle class consumption from the global South: A study of everyday ethics in South Africa's Western Cape. Geoforum, 67, 233-243.

81. McIntosh, W. A. (2013). Sociologies of food and nutrition. Springer Science \& Business Media. 
82. McLeod, J. (2013). An Introduction to Counselling, 5E. McGraw-Hill International.

83. Miller, J. G., Bland, C., Källberg-Shroff, M., Tseng, C. Y., Montes-George, J., Ryan, K., ... \&Chakravarthy, S. (2014). Culture and the role of exchange vs. communal norms in friendship. Journal of Experimental Social Psychology, 53, 79-93.

84. Moran, R. T., Abramson, N. R., \& Moran, S. V. (2014). Managing cultural differences. Routledge.

85. Naor, M., Jones, J. S., Bernardes, E. S., Goldstein, S. M., \& Schroeder, R. (2013). The culture-effectiveness link in a manufacturing context: A resource-based perspective. Journal of World Business, 49(3), 321-331.

86. Neumark-Sztainer, D., Eisenberg, M., Fulkerson, J. A., Story, M., and Larson, N. I. (2008). Family meals and disordered eating in adolescents. Archives Pediatric and Adolescent Medicine, 162, 17-22.

87. Niebuhr, R. (2013). Moral man and immoral society: A study in ethics and politics. Westminster John Knox Press.

88. Oh, J. H., Kim, H. S., \& Lee, J. H. (2014). Asian Cultural Collectivism, Acculturation, and Life Satisfaction among Ethnic Asian Brides in South Korea. Asian Women, 30(3), 23-56.

89. Paine, C. (2013). Religious objects in museums: Private lives and public duties. A\&C Black.

90. Pandey, V., \& Joseph, G. K. (2014). Changing Perceptions of Fairness: Group Identity, Locus of Merit and Need, and the Preference for Norms of Allocation. International Journal of Social Sciences, $3,1$.

91. Pargament, K. I., \& Lomax, J. W. (2013). Understanding and addressing religion among people with mental illness. World Psychiatry, 12(1), 26-32.

92. Parks, C. D., Joireman, J., \& Van Lange, P. A. (2013). Cooperation, trust, and antagonism how public goods are promoted. Psychological science in the public interest, 14(3), 119-165.

93. Pearce, J., \& Langley-Evans, S. C. (2013). The types of food introduced during complementary feeding and risk of childhood obesity: a systematic review. International Journal of Obesity, 37(4), 477-485.

94. Pérez, F. M. I. (2014). Cultural Values and their Correlation with Interactional Metadiscourse Strategies in Spanish and us Business Websites. Atlantis. Journal of the Spanish Association for Anglo-American Studies, 36(2), 73-95.

95. Perry-Jenkins, M., Newkirk, K., \&Ghunney, A. K. (2013). Family work through time and space: An ecological perspective. Journal of Family Theory \& Review, 5(2), 105-123.

96. Philips, N., Sioen, I., Michels, N., Sleddens, E., \& De Henauw, S. (2014). The influence of parenting style on health related behaviour of children: findings from the ChiBS study. International Journal of Behavioural Nutrition and Physical Activity, 11(1), 95.

97. Pimpin, L., Ambrosini, G. L., Llewellyn, C. H., Johnson, L., van Jaarsveld, C. H., Jebb, S. A., \& Wardle, J. (2013). Dietary intake of young twins: nature or nurture?.The American journal of clinical nutrition, 98(5), 1326-1334.

98. Pirutinsky, S. (2009). The terror management function of Orthodox Jewish religiosity: A religious culture approach. Mental Health, Religion and Culture, 12(3), 247-256.

99. Pompper, D. (2014). Considering Faith and Spirituality Practices and Worldviews in Organizations. International Perspectives on Equality, Diversity and Inclusion, 1, 187-203.

100.Posthuma, R. A., \& Guerrero, L. (2013). Age stereotypes in the workplace: Multidimensionality, cross-cultural applications, and directions for future research. The SAGE Handbook of Aging, Work and Society, Sage.

101.Pressman, R. M., Owens, J. A., Evans, A. S., \&Nemon, M. L. (2014). Examining the Interface of Family and Personal Traits, Media, and Academic Imperatives Using the Learning Habit Study. The American Journal of Family Therapy, 42(5), 347-363.

102.Reeve, J., Deci, E. L., \& Ryan, R. M. (2004). Self-determination theory: A Dialectical Framework for Understanding Sociocultural Influences on Student. Big theories revisited, 4, 31.

103.Roberts, J. M. (2014). Digital Publics: Cultural Political Economy, Financialisation and Creative Organisational Politics (Vol. 138). Routledge.

104.Roopnarine, J. L., \& Hossain, Z. (2013). African American and African Caribbean Fathers. Handbook of Father Involvement: Multidisciplinary Perspectives, Routledge.

105.Rosmarin, D. H., Pirutinsky, S., Pargament, K. I., \&Krumrei, E. J. (2009). Are religious beliefs relevant to mental health among Jews?. Psychology of Religion and Spirituality, 1(3), 180.

106. Rozman, G. (Ed.). (2014). The East Asian region: Confucian heritage and its modern adaptation. Princeton University Press.

107.Scales, P. C., Syvertsen, A. K., Benson, P. L., Roehlkepartain, E. C., \&Sesma Jr, A. (2014). Relation of Spiritual Development to Youth Health and Well-Being: Evidence from a Global Study. In Handbook of Child Well-Being (pp. 1101-1135). Springer Netherlands. 
108.Schäfer, I. (2014). A Matrix for Mediterranean (Area) Studies-Towards an Interdisciplinary Approach in the Post-“Arab Spring” Context. Mediterranean review, 7(1), 57-89.

109.Seifer, R., Dickstein, S., Parade, S., Hayden, L. C., Magee, K. D., \& Schiller, M. (2014). Mothers' appraisal of goodness of fit and children's social development. International Journal of Behavioural Development, 38(1), 86-97.

110.Slater, D., \&Tonkiss, F. (2013). Market society: Markets and modern social theory. John Wiley \& Sons.

111.Sussman, S., Milam, J., Arpawong, T. E., Tsai, J., Black, D. S., \& Wills, T. A. (2013). Spirituality in Addictions Treatment: Wisdom to Know... What It Is. Substance use \& misuse, 48(12), 1203-1217.

112.Tan, F. W. (2014). The Mean Thought of Chinese Traditional Architecture. In Applied Mechanics and Materials, Vol. 638, pp. 2261-2264.

113.Thornhill, R., \& Fincher, C. L. (2014). Human Values Research Prior to the Parasite-Stress Theory. In The Parasite-Stress Theory of Values and Sociality (pp. 83-111). Springer International Publishing.

114.Timothy, D. J. (2013). Tourism, war, and political instability. Tourism and War, Routledge.

115.Ungar, M. (2015). Practitioner Review: Diagnosing childhood resilience-a systemic approach to the diagnosis of adaptation in adverse social and physical ecologies. Journal of child psychology and psychiatry, 56(1), 4-17.

116.Usunier, J.C. and Lee, J.A. (2009) Marketing Across cultures, 5th edition - Pearson education Limited.

117.Usunier, J.C. and Lee, J.A. (2009) Marketing Across cultures, 5th edition - Pearson education Limited.

118.Vaiman, V., \& Brewster, C. (2014). How far do cultural differences explain the differences between nations? Implications for HRM. The International Journal of Human Resource Management, 26(2), 151-164.

119.Valchev, V. H., Nel, J. A., Van de Vijver, F. J., Meiring, D., De Bruin, G. P., \&Rothmann, S. (2013). Similarities and differences in implicit personality concepts across Ethno-cultural groups in South Africa. Journal of Cross-Cultural Psychology, 44(3), 365-388.

120.Wald, K. D., \& Calhoun-Brown, A. (2014). Religion and politics in the United States. Rowman \& Littlefield.

121.Wald, K. D., \& Calhoun-Brown, A. (2014). Religion and politics in the United States. Rowman \& Littlefield.

122.Wang, H., Rober, P., Dillen, A., \&Enzlin, P. (2014). The Impact of Stressful Life Events on Highly Religious Chinese Christians Living in Belgium. Journal of religion and health, 54(2), 495-516.

123. Whitman, S., \& Liebenberg, L. (2015). Barriers to Resilience Processes: Understanding the Experiences and Challenges of Former Child Soldiers Integrating into Canadian Society. In Youth Resilience and Culture (pp. 157-169). Springer Netherlands.

124.Windram-Geddes, M. (2013). Fearing fatness and feeling fat: Encountering affective spaces of physical activity. Emotion, Space and Society, 9, $42-49$.

125.Wulff, D. (2014). Psychology of religion. In Encyclopaedia of psychology and religion (pp. 1424-1429). Springer US.

126. Yassine-Hamdan, N., \& Pearson, F. S. (2014). Arab Approaches to Conflict Resolution: Mediation, Negotiation and Settlement of Political Disputes. Routledge.

127.Yolles, M., \& Fink, G. (2014). Changing the Corporate Paradigm: from the Duality of IndividualismCollectivism to Complementarism. The International Journal of Public and Private Management, 1(1), 1-51.

128.Zhao, B. (2014). Posthumous Reputation and Posthumous Privacy in China: The Dead, The Law, And The Social Transition. Brooklyn J. Int'l L., 39, 269-521. 